\title{
Loanwords and Pragmatic Competence
}

\section{Jeffrie Butterfield \\ Nihon University}

\section{Reference Data:}

Butterfield, J. (2020). Loanwords and pragmatic competence. In P. Clements, A. Krause, \& R. Gentry (Eds.), Teacher efficacy, learner agency. Tokyo: JALT. https://doi.org/10.37546/JALTPCP2019-33

The extensive number of English loanwords in Japanese can be an invaluable resource for language learners in Japan and knowledge of them can aid in the recognition and comprehension of English vocabulary. However, because comparatively few of the English loanwords used in Japanese share all of the same meanings and usages with their English source words, it can lead to grammatical, semantic, and pragmatic errors if language learners are not aware of the similarities and differences, which are rarely taught in language classrooms. In this paper I explore factors related to English loanwords in Japanese that can affect language learners' pragmatic competence in English. These factors include semantic narrowing and expansion, contextual narrowing and expansion, cross-linguistic transfer, and pragmatic transfer. I also discuss the importance of teaching loanwords and pragmatic knowledge in language classrooms.

日本語の中で使用される多くの英語由来の外来語は、日本の英語学習者には極めて有用な資源であり、外来語の知識は、 英単語の認識や理解に役立つ。元の英語と、意味や使い方が同様の英語由来の外来語は比較的に少なく、言語教室で取り上 げられる事もあまりない。元の英語と外来語の類似点、相違点の知識がなければ、文法的、意味論的、語用論的な間違いに発 展する可能性がある。本研究では、英語由来の外来語に関する意味や文脈の縮小・拡大、母語の移転や語用論的移転といった 英語学習者の語用論的な能力に影響を与える要素を探索する。また、外来語や語用論的な知識を教授することの重要性を論 じる。

ow language learners acquire lexical, grammatical, and phonological knowledge L has long been the focus of many studies on second language acquisition. However, merely acquiring this linguistic knowledge does not necessarily lead to being competent in a language. This realization has led researchers in the field of second language acquisition to question what it really means to be competent in a second language as well as how learners can acquire the knowledge needed to become competent. The pursuit of these questions has resulted in an increase of studies on pragmatics that consider issues such as pragmatic transfer (e.g., Bou Franch, 1998), pragmatic competence (e.g., Kasper, 1997; Rueda, 2006; Takahashi \& Beebe, 1987), and interlanguage pragmatics (e.g., Jianda, 2006), a subfield of research on second languages (Kasper, 1992) that studies "nonnative speakers' use and acquisition of linguistic action patterns in a second language" (Kasper \& Blum-Kulka, 1993, p. 3).

Many studies on interlanguage pragmatics examine how learners perform various speech acts, such as compliments, apologies, and invitations. In recent years there has been an increasing number of studies on second language pragmatic competence, but as Oki (2016) pointed out, "Little research has been done to investigate the relationship between pragmatic awareness and one specific aspect of organizational knowledge, vocabulary knowledge" (p. 24). The knowledge that Japanese learners have of the meanings and usages of English loanwords in Japanese can impact their ability to produce grammatically and semantically accurate sentences in pragmatically appropriate contexts. This paper explores various factors related to loanwords that can affect language learners' pragmatic competence in English.

\section{Loanword Usage in Japanese}

Lexical borrowing across languages has been a common practice ever since there has been language contact among people of different linguistic backgrounds. For example, there was language contact between Japanese and the Jesuits who spoke Portuguese during the Iberian period, the first epoch of loanword history in Japan that lasted for approximately 100 years from the middle of the 16th century (Irwin, 2011). In spite of the minimal amount of contact with other languages that people in Japan have and have had, the scale of lexical borrowing in Japanese is comparable to that of English (Irwin, 
2011). The main difference is that the majority of borrowing in English took place when English was still in its relative infancy compared to the recent borrowings into Japanese. Despite Japanese being an established language and that there has been a limited amount of language contact since the end of World War Il, the number of loanwords that have entered Japanese has increased at an unparalleled rate in recent years.

Loanword is challenging to define because of the inability to determine at what point a foreign word becomes a loanword-a borrowed word intelligible to the majority of the speakers of a particular language. Because the comprehension levels of words are constantly in flux, the boundary between a foreign word and a loanword remains ambiguous. For the purpose of this paper, I am using loanword to mean a word adopted from another language and used by a large number of members of a speech community.

Looking at the number of entries in a Japanese dictionary dedicated to loanwords helps to put the scale of loanword usage into perspective. The コンサイスカタカナ語辞典 (Concise Katakana Word Dictionary, 2010) consists of 56,300 total entries, the majority of which are of English origin. (In Japanese, loanwords are written in the katakana syllabary.) What is more surprising than the scale of lexical borrowing in Japanese is that regardless of the vast number of loanwords that are used, Japanese students generally have lower scores on standardized tests that measure English proficiency than do students in countries whose languages contain significantly fewer English loanwords. On the TOEIC Listening and Reading Test, for example, Japan came in at 44th out of 49 countries (Educational Testing Service, 2019), but no one has been able to identify the exact cause of the low level of English proficiency in Japan (Taguchi, 2006).

\section{Pragmatics, Pragmatic Accuracy, and Pragmatic Competence}

There are numerous definitions of pragmatics. Thomas (1995) defined pragmatics as a process that involves "the negotiation of meaning between speaker and hearer, the context of utterance (physical, social and linguistic) and the meaning potential of the utterance" (p. 22). In this definition, the emphasis is on meaning and context, whereas other definitions place emphasis on language use and how it affects other interlocutors. Crystal (1997), for example, viewed pragmatics as "the study of language from the point of view of users, especially of the choices they make, the constraints they encounter in using language in social interaction and the effects their use of language has on other participants in the act of communication" (p. 301).

The term pragmatics is often used in second language research in a more general sense to denote the study of language use in social contexts. Pragmatic accuracy refers to grammatically and semantically accurate language use in a single pragmatically appropriate context. It is possible for a language learner who is not pragmatically competent in their second language to produce a correct sentence in an appropriate context and therefore be pragmatically accurate. Language learners can achieve pragmatic competence, which Koike (1989) defined as "the speaker's knowledge and use of rules of appropriateness and politeness which dictate the way the speaker will understand and formulate speech acts" (p. 279). Pragmatic competence is realized when learners are able to produce nativelike, grammatically, and semantically accurate expressions that are contextually appropriate in a multitude of situations.

\section{Factors Related to Loanwords That Can Affect Pragmatic Competence}

Chomsky (1980) distinguished between grammatical competence and pragmatic competence, stating that the former is limited to "the knowledge of form and meaning" , whereas the latter refers to the "knowledge of conditions and manner of appropriate use, in conformity with various purposes" (p. 224). Kecskes (2015) summarized the differences between grammatical competence and pragmatic competence: "Grammatical competence is about correctness while pragmatic competence is more about appropriateness" (p. 421). In this paper I distinguish between grammatical accuracy (form) and semantic accuracy (meaning) in order to highlight issues related to the meanings of English loanwords that language learners in Japan face and how they can affect pragmatic competence. One way in which pragmatic competence may be displayed is word choice (Kecskes, 2015). However, in research on pragmatics, the focus is predominantly on the contextual appropriateness of clusters of words, such as sentences and expressions. Studies considering the impact of lexical knowledge on pragmatic competence are still lacking. This section explores various factors related to English loanwords in Japanese that can affect language learners' pragmatic competence.

\section{Semantic Narrowing and Expansion}

One issue that Japanese learners of English face is the semantic narrowing or expansion of loanwords. Some English loanwords in Japanese have fewer meanings than their source words; sometimes they take on additional meanings. For example, the English word tension is often used as a loanword in Japanese to mean a feeling of energy, which is not a meaning that the English word has. The most common usage of tension in Japanese is 彼はテンションが高い [kare wa tenshon ga takai] meaning “He has a lot of energy." If a learner assumed that the loanword テンション [tenshon] shared the same meaning and usage in English, it could result in a sentence such as "He has a lot of tension," which is grammatically correct, but semantically incorrect. Another example 
is the loanword ホーム [hömu], which means both train platform and home, as in house. The meaning of the sentence “私は駅のホームにいる” [watashi wa eki no hoomu ni iru] is "I am on the station platform," but because platform and home are both written as ホー ム [hoomu], some learners may misstate, "I am on the station home." Language learner who are unaware of the differences in meaning and usage of テンション [tenshon] and ホ ーム [hoomu] in Japanese and in English could easily make mistakes, especially because loanwords are not often addressed in Japanese or English classes. The English word tension and English loanword in Japanese テンション [tenshon] do share a few similar definitions. For example, the degree to which something is stretched and a nervous feeling are definitions that both words have in common, but a corpus analysis using Kotonoha (https://shonagon.ninjal.ac.jp/), a corpus database of written Japanese, revealed that both of these usages are comparatively rare in Japanese.

English loanwords can be an amazing resource for language learners in Japan (Daulton, 2008), especially at lower levels, as they can help learners to communicate. However, loanwords can also have many drawbacks. The semantic narrowing or expansion of loanwords can lead to disfluency and contextually inappropriate usage when language learners are not aware of the differences. Loanwords can affect not only semantic accuracy but grammatical accuracy as well when students perceive a word to be similar in usage to that of the loanword in Japanese. Daulton (2007) explored the impact of English loanwords in Japanese on English language learners' production of English and discovered that there was a "borrowed word effect" (p. 17), meaning a preference for the use of loanwords over nonloanwords. However, just because there is a preference among language learners to use English loanwords does not mean that users have a high degree of comprehension of the loanwords, nor that their usage is semantically or grammatically accurate. According to Nation (2001), understanding a word entails having knowledge of its form, meaning, and use. Knowledge of form and meaning can often be obtained by using a textbook or dictionary, but knowledge about how and when to use a word can be acquired either through explicit instruction or through a significant amount of exposure to natural language in natural contexts.

\section{Contextual Narrowing and Expansion}

The contextual narrowing or expansion of loanwords can create problems for English language learners in Japan. When English loanwords are used in Japanese, they can be used in more or fewer contexts than their source words, and some of these contexts may overlap or be completely different. Even if the meaning of a loanword and its source word are similar, they may be used in completely different contexts. Because of the lack of instruction regarding loanwords, language learners often lack the semantic and pragmatic knowledge needed to make informed decisions. This lack of knowledge can cause them to make word choices based on the perceptions that they have about the meanings and usages of the loanwords in Japanese, which may or may not be similar to the English source words. Although most words have more than one meaning and are used in a variety of contexts, some words may only have a few meanings and be used in very specific contexts. Without the knowledge of the numerous combinations of meanings and usages that English source words have, it can be extremely difficult for language learners to produce grammatically, semantically, and pragmatically accurate sentences.

Brown (2003) posed the following question: "Why is it that we let students learn one meaning for each word, when we know for a fact that words have many meanings?" (p. 4). A similar question can be asked about loanwords. Why is it that even though in many cases one loanword in Japanese corresponds to several words in English, the words that they correspond to are rarely taught in classrooms? A significant issue for English language learners in Japan is not just that many of the meanings of loanwords are often restricted in Japanese, but that the contexts in which they are commonly used are often completely different to that of English.

\section{Cross-Linguistic Transfer and Pragmatic Transfer}

Previous studies (e.g., Taylor, 1975) have shown that transfer occurs more commonly among learners who have a low degree of linguistic proficiency. Transfer can be crosslinguistic or pragmatic and can be due to a variety of reasons. Cross-linguistic transfer occurs when a language learner's first language affects their understanding and use of their second language. Positive transfer can happen when the meaning of a word in a language learner's first language is similar to that in their second language. Struc and Wood (2015) noted that "The nature of the cognate and its usage in Japanese may result in L2 English usage which is ungrammatical or semantically inappropriate" (p. 18). Depending on whether an English loanword in Japanese is a true cognate or not can affect language learners' ability to use that loanword correctly when they are speaking or writing English. If the meaning of the English loanword is different and learners are not aware of the difference, it can result in negative transfer.

Pragmatic transfer in a second language can occur when a learner's knowledge of their language and culture affects their second language usage. According to Kasper and Schmidt (1996), learners may make pragmatic mistakes because "learners' sociopragmatic knowledge is not yet sufficiently developed for them to make culturally appropriate 
choices of strategies and linguistic forms" (p. 157). Pragmatic knowledge of a second language can be assisted by applying universally held principles of pragmatic usage and through transfer from the first languages of learners (Rueda, 2006). There are pragmatic usages that overlap between languages. Language learners are pragmatically competent in their first language and part of that competence may be universal and therefore result in positive pragmatic transfer in their second language. Negative pragmatic transfer can occur when learners are unaware of the differences in usage between loanwords and their source words. Teaching learners the similarities and differences in usage between loanwords and their source words can help learners to avoid negative pragmatic transfer and to develop pragmatic competence.

\section{Teaching Loanwords and Pragmatics in Language Classrooms}

Some research (e.g., Blum-Kulka, House, \& Kasper, 1989) has addressed the importance of teaching pragmatics in language classrooms. Pragmatic knowledge is rarely taught in language classrooms (Jianda, 2006) despite the need to achieve a high level of proficiency in a language. Grammatical knowledge is often acquired without the pragmatic knowledge of how and when to use a particular lexical item. Many language classrooms still employ the traditional initiation-response-feedback (IRF) sequence, which is when a teacher asks a question, the student responds, and the teacher provides feedback (Butterfield \& Bhatta, 2015). IRF sequences allow students to practice using grammar structures, expressions, and so on without any context. This way of teaching can help learners to acquire linguistic knowledge that will improve their semantic and grammatical accuracy, but it will still leave them unequipped with the knowledge needed to achieve a high degree of pragmatic competence.

Bardovi-Harlig (2001) pointed out that just because a learner has a high level of grammatical competence, it does not necessarily equate to a high level of pragmatic competence. There have been studies that substantiate this claim (e.g., Jianda, 2006). Oki (2016) investigated how grammatical and pragmatic competence were affected by learners' second language lexical knowledge. She found that the lexical knowledge that learners possessed had an effect on their ability to recognize pragmatic and grammatical mistakes, but that it was more beneficial in helping students to detect the latter. This makes sense because vocabulary and grammar are taught in language classrooms, whereas pragmatic knowledge is hardly ever taught. According to Brown (2003), students mainly learn vocabulary, grammar, and pronunciation in language classrooms, but "paralinguistic features, kinesic language features, and pragmatics" (p. 4) are also necessary in order to achieve competency in a language.
Judging from the lack of attention that loanwords receive in language classrooms in Japan, there seems to be an assumption that English loanwords in Japanese and their English donor words share all of the same meanings and usages, so there is no need to teach or discuss them. Teaching the similarities and differences in meaning and usage between English loanwords and their source words in English would enable language learners to strengthen their lexical foundations and to acquire the pragmatic knowledge needed to achieve pragmatic competence. However, because of the lack of explicit instruction regarding loanwords, many learners may have assumptions and misconceptions about loanwords and lack lexical or pragmatic knowledge, often leading to negative transfer in the form of semantic, pragmatic, and grammatical errors. Ideally, lessons specifically dedicated to raising learners' awareness about loanwords should be implemented to help learners realize that loanwords can be an amazing resource, but that differences in meaning and usage do exist between loanwords and their source words. These similarities and differences can also be addressed when English words that have become loanwords appear in textbooks and other classroom materials or when learners misuse loanwords on writing assignments or during speaking activities.

\section{Conclusion}

Becoming competent in a language requires much more than just understanding grammar and an extensive amount of vocabulary; knowledge of when, where, and how to use language is also necessary. Even if all of the English loanwords used in Japanese were true cognates, it would not result in a significant improvement in pragmatic competence as a similar meaning does not guarantee a similar usage. Some loanwords share at least one similar meaning and usage to their English source words, so even without knowledge of their meanings and usages in English it is still possible to produce pragmatically accurate sentences. However, because most words have several meanings and usages, choosing the correct word and producing it in an appropriate context can be a daunting task for language learners, especially considering that the similarities and differences in meaning and usage of loanwords are rarely taught in language classrooms in Japan. In addition, pragmatic usage of nonloanwords is also seldom taught. Many language teachers use textbooks that contain short conversations with little to no context, making it difficult for language learners to develop a high level of pragmatic competence. The findings of some studies (e.g., Oki, 2016) suggest that there is a need to teach both vocabulary and pragmatic awareness in order to help students improve their overall pragmatic competence. 
This paper has explored factors related to English loanwords in Japanese that can affect language learners' pragmatic competence in English. The semantic and contextua narrowing and expansion of loanwords can have an impact on language learners' pragmatic competence. A significant number of language learners, especially those with a low level of proficiency, often assume that loanwords share the same meanings and usages as their English source words. Developing a deeper understanding of the meanings of loanwords would help learners to strengthen their lexical foundations and better utilize them. However, lexical knowledge alone is insufficient for improving pragmatic competence; pragmatic knowledge is also necessary. Cohen (2004) stated that "it is often not enough to string a series of words together grammatically; they must be in a meaningful sociocultural context as well" (p. 2). For English language learners in Japan, not only having knowledge of the meaning of loanwords, but also being able to use them in socioculturally appropriate contexts is essential to develop a high level of competence in English. Explicit instruction regarding the similarities and differences in meaning and usage of loanwords and their English counterparts will enable language learners to overcome the various issues related to loanwords and to improve their pragmatic competence.

\section{Bio Data}

Jeffrie Butterfield teaches at the Nihon University College of Economics. His current research interests include conversation analysis, second language acquisition, and language teaching. <jeffriebutterfield@gmail.com>

\section{References}

Bou Franch, P. (1998). On pragmatic transfer. Studies in English Language and Linguistics, 0, 5-20. Retrieved from https://www.uv.es/ boup/PDF/Sell-98.pdf

Bardovi-Harlig, K. (2001). Evaluating the empirical evidence: Grounds for instruction in pragmatics? In K. R. Rose \& G. Kasper (Eds.), Pragmatics in language teaching (pp. 13-32). Cambridge, England: Cambridge University Press.

Blum-Kulka, S., House, J., Kasper, G. (1989). Investigating cross-cultural pragmatics: An introductory overview. In S. Blum-Kulka, J. House, \& G. Kasper (Eds.), Cross-cultural pragmatics (pp. 1-34). Norwood, NJ: Ablex.

Butterfield. J., \& Bhatta, B. (2015). IRF sequences in team-teaching EFL classrooms. The Asian Journal of Applied Linguistics, 2(3), 176-185. Retrieved from

https://caes.hku.hk/ajal/index.php/ajal
Brown, J. D. (2003). Promoting fluency in EFL classrooms. Proceedings of the 2nd Annual JALT PanSIG Conference, 1-12, Retrieved from http://hosted.jalt.org/pansig/2003/HTML/Brown.htm

Cohen, A. D. (2004). The interface between interlanguage pragmatics and assessment. Proceedings of the 3rd Annual JALT PanSIG Conference, 1-8, Retrieved from

http://hosted.jalt.org/pansig/2004/HTML/Cohen.htm

コンサイスカタカナ語辞典 [Concise katakana word dictionary] (4th ed.). (2010). Tokyo: Sanseido.

Crystal, D. (1997). English as a global language. Cambridge, England: Cambridge University Press. Chomsky, N. (1980). Rules and representations. New York, NY: Columbia University Press.

Daulton, F. E. (2007). Japanese learners' built-in lexicon of English and its effect on L2 production. The Language Teacher, 31(9), 15-18. Retrieved from https://jalt-publications.org/tlt/issues/2007-09_31.9

Daulton, F. E. (2008). Japan's built-in lexicon of English-based loanwords. Clevedon, England: Multilingual Matters.

Educational Testing Service (2019). 2018 report on test takers worldwide. Retrieved from https://www.ets.org/s/toeic/pdf/2018-report-on-test-takers-worldwide.pdf

Irwin, M. (2011). Loanwords in Japanese. Amsterdam, The Netherlands: John Benjamins.

Jianda, L. (2006). Assessing EFL learners' interlanguage pragmatic knowledge: Implications for testers and teachers. Reflections on English Language Teaching, 5(1), 1-22.

Kasper, G. (1992). Pragmatic transfer. Second Language Research, 8(3), 203-231. https://doi.org/10.1177/026765839200800303

Kasper, G. (1997). Can pragmatic competence be taught? University of Hawai’i Second Language Teaching \& Curriculum Center NetWork \#6, Retrieved from http://www.nflrc.hawaii.edu/NetWorks/Nw6/

Kasper, G. \& Blum-Kulka, S. (1993). Interlanguage pragmatics. (In G. Kasper \& S. Blum-Kulka (Eds.), Interlanguage pragmatics: Current research issues (pp. 3-19). New York, NY: Oxford University Press.

Kasper, G. \& Schmidt, R. (1996). Developmental issues in interlanguage pragmatics. Studies in Second Language Acquisition, 18, 149-169. https://doi.org/10.1017/S0272263100014868

Koike, D. A. (1989). Pragmatic competence and adult L2 acquisition: Speech acts in Interlanguage. The Modern Language Journal, 73(3), 279-289. https://doi.org/10.2307/327002

Kecskes, I. (2015). How does pragmatic competence develop in bilinguals? International Journal of Multilinguals, 12(4), 419-434. https://doi.org/10.1080/14790718.2015.1071018

Nation, I. S. P. (2001). Learning vocabulary in another language. Cambridge, England: Cambridge University Press. 
Oki, N. (2016). Japanese EFL learners' L2 pragmatic and grammatical awareness in relation to vocabulary knowledge. 北海学園大学人文論集 [Hokkai-Gakuen University Studies in Humanities], 61, 23-46.

Rueda, Y. T. (2006). Developing pragmatic competence in a foreign language. Colombian Applied Linguistics Journal, 8, 169-182. https://doi.org/10.14483/22487085.177

Struc, N., \& Wood, N. (2015). Crosslinguistic lexical transfer of English-based loanwords in English

L2 writing by Japanese university students. Bergen Language and Linguistic Studies (BeLLS) Learner

Corpus Research: LCR2013 Conference Proceedings 2015, 6, 5-22.

https://doi.org/10.15845/bells.v6i0.806

Takahashi, T., \& Beebe L. M. (1987). The development of pragmatic competence by Japanese learners of English. JALT Journal, 8(2), 131-155. Retrieved from https://jalt-publications.org/sites/default/files/pdf-article/jj-8.2-art3.pdf

Taguchi, K. (2006). English in Japanese. The Economic Review of Toyo University, 32, 67-76. Retrieved from http://id.nii.ac.jp/1060/00001700/

Taylor, B. (1975). The use of overgeneralization and transfer learning strategies by elementary and intermediate students in ESL. Language Learning, 25(1), 73-107. https://doi.org/10.1111/j.1467-1770.1975.tb00110.x

Thomas, J. (1995). Meaning in interaction: An introduction to pragmatics. Harlow, England: Longman. 